\title{
Analysis of Farming and Marketing Efficiency Of Green Beans In Muna Regency Of Southeast Sulawesi Province
}

\author{
La Ode Geo \\ Agribusiness Department of Agriculture Faculty of Halu Oleo University
}

\begin{abstract}
Food security is a national and international issue which continues to be researched on how to solve it over time. One of the food commodities developed by the government and facing problems in its exploitation is green beans. The objectives of the research were (1) to know farming efficiency of green beans in Muna regency; and (2) to know marketing efficiency in Muna Regency. This research was conducted in Muna Regency as main central of green beans producer in Southeast Sulawesi from August to December 2015. Research sample were 66 farmer respondents who were selected based on three-stage cluster purposive sampling technique. The data type were primary and secondary data. The data collecting method used structured interview based on the questionnaire. Method of data analysis used descriptive statistic and farming efficiency $R / C$ Ratio were the. Research result showed that green beans farming was relatively efficient as showed by $R / C$ value 2,59. This fact assigned that for every green beans farming expenditure in the amount of IDR 1 will obtain the farming return of IDR 2,59. Likewise for the green beans marketing system in Muna Regency was relatively efficient as shown by shared price that was accepted by farmers accounted for 53,12 percents, nevertheless the transportation cost was still adequate high as a result of poor road infrastructure to the villages or districts of the regency.
\end{abstract}

Keywords: efficiency, farming, marketing, grean beans

\section{Introduction}

Food security is a national and international issue which continues to be researched on how to solve it over time. Agriculture is one of the most important sectors in the national economy of Southeast Sulawesi Province. Therefore, this sector should be able to be developed as a main sector and mobalizer of national and regional economy. One of the ways that can be done is optimizing the utilization of domestic resources (land, water, labor, capital and technology) thus it could improve farmers and consumers welfare in a balanced way (Geo L, 2005).

In Indonesia, Green beans (Vigna radiata) is one of the third strategic food commodities after soybeans and peanuts. In addition to food, it also can be used as industrial raw materials, andeven its leaves can be utilized for animal feed and fertilizer. Geo, L. and Harafah, L.M (2014) suggested that green beans contained high nutritional value namely Fat, Protein, Carbohydrates, and Vitamins.

Domestic production capability in supplying green beans is highly low when compared to consumen' demand thus it requires some efforts to meet the gap between demand and supply. These efforts can be done through intensification in production center, intensification, and diversification based on resource potential. Strategies based on the advantages of local resources such as land use, labor, capital, and others are among the efforts to improve farming efficiency in order to reduce imports thereby can create competitive advantage. This can be realized if the ongoing and future policies can provide support for the growth and development of green beans. In limited water availability is areas, such as dry land and in rainfed lowland farms, farmers usually consider more alternative types of crops to cultivate with the aim of obtaining higher net income with technology they have mastered. Nevertheless, the technology that farmers apply to each commodity is not advanced technology that gives the highest returns for them. It is due to various constraints such as the limited information and limited capital they have. Since neighboring farmers may grow different crops so that the production of a food commodity in an area is rather difficult to predict in a particular season or year.

Muna Regency is one of the regencies in Southeast Sulawesi province that has potential for the development of green beans. This is because Muna Regency has a large agricultural land and can be used for the cultivation of this crop. Based on statistical data and Agricultural Office of Southeast Sulawesi Province in 2015 showed that the harvested area, production and productivity levels in Muna Regency over the past 12 years presented a fluctuative development as shown in table 1. 
Table 1. The development of harvested area, production and productivity of green beans in Muna regency from 2004 to 2015

\begin{tabular}{|c|c|c|c|c|c|c|c|c|c|c|c|c|c|c|}
\hline \multirow[t]{2}{*}{$\mathrm{Nu}$. } & Years/ & \multirow[t]{2}{*}{2004} & \multirow[t]{2}{*}{2005} & \multirow[t]{2}{*}{2006} & \multirow[t]{2}{*}{2007} & \multirow[t]{2}{*}{2008} & \multirow[t]{2}{*}{2009} & \multirow[t]{2}{*}{2010} & \multirow[t]{2}{*}{2011} & \multirow[t]{2}{*}{2012} & \multirow[t]{2}{*}{2013} & \multirow[t]{2}{*}{2014} & \multirow[t]{2}{*}{2015} & \multirow[t]{2}{*}{ Average } \\
\hline & Regencies & & & & & & & & & & & & & \\
\hline 1 & Buton & 67 & 58 & 116 & 76 & 76 & 64 & 78 & 10 & 71 & 99 & 25 & 26 & 63.83 \\
\hline 2 & Muna & 232 & 244 & 207 & 228 & 195 & 114 & 117 & 122 & 89 & 73 & 83 & 84 & 148.97 \\
\hline 3 & Konawe & 624 & 640 & 583 & 800 & 689 & 300 & 90 & 125 & 94 & 84 & 70 & 71 & 347.50 \\
\hline 4 & Kolaka & 387 & 402 & 286 & 262 & 214 & 208 & 183 & 322 & 261 & 97 & 23 & 23 & 222.34 \\
\hline 5 & $\begin{array}{l}\text { South } \\
\text { Konawe }\end{array}$ & 158 & 160 & 153 & 317 & 351 & 194 & 172 & 190 & 131 & 113 & 150 & 149 & 186.50 \\
\hline 6 & Bombana & 51 & 54 & 42 & 67 & 63 & 32 & 54 & 38 & 48 & 60 & 37 & 37 & 48.59 \\
\hline 7 & Wakatobi & & & & 1 & & & & & & & 2 & 3 & 0.50 \\
\hline 8 & $\begin{array}{l}\text { North } \\
\text { Kolaka }\end{array}$ & & 20 & 69 & 61 & 41 & 31 & 27 & 76 & 119 & 59 & 44 & 43 & 49.17 \\
\hline 9 & $\begin{array}{l}\text { North } \\
\text { Buton }\end{array}$ & & & & & & 33 & 8 & 10 & 105 & 81 & 97 & 98 & 36.00 \\
\hline 10 & $\begin{array}{l}\text { North } \\
\text { Konawe }\end{array}$ & & & & & & 145 & 167 & 621 & 141 & 342 & 798 & 789 & 250.25 \\
\hline 11 & East Kolaka & & & & & & & & & & 67 & 269 & 273 & 50.75 \\
\hline 12 & $\begin{array}{l}\text { Konawe } \\
\text { Island }\end{array}$ & & & & & & & & & & 7 & 8 & 11 & 2.17 \\
\hline 13 & Kendari & 10 & 12 & 6 & 16 & 2 & 8 & 4 & 11 & 6 & & & & 6.25 \\
\hline 14 & Bau-Bau & 9 & 11 & 12 & 4 & 8 & 3 & 2 & 2 & 2 & 1 & & & 4.50 \\
\hline 15 & Sultra Prov. & 1,538 & 1,601 & 1,474 & 1,832 & 1,639 & 1,132 & 902 & 1,527 & 1,067 & 1,083 & 1,606 & 1,607 & 1417.31 \\
\hline
\end{tabular}

Source: Agricultural Office of Southeast Sulawesi Province in 2016 (processed)

The main problem faced by green beans farmers in Muna regency was the level of production which had not been maximized. It was because the farmers had not run a good agricultural intensification system including the use of seeds or superior seeds, good water system, pestand plant disease control and fertilizer usage as recommended dosage. In addition, to achieve maximum production in a farming branch is needed to integrate various means of production and labor effectively and efficiently as maximum production will be obtained when these matters combined thus production cost will reduce and farmers' income will increase.

Furthermore, the development of various food crops such as green beans face the challenge to be able to meet the needs of household consumption and domestic raw materials needs. Thereby, it is necessary to examine the level of farming and marketing efficiency of green beans.

\section{Farming}

\section{Literature Review}

A farm is an area of land that is devoted primarily to agricultural processes with the primary objective of producing food and other crops; it is the basic facility in food production (Gregor, Howard F., 1969). The name is used for specialised units such as arable farms, vegetable farms, fruit farms, dairy, pig and poultry farms, and land used for the production of natural fibres, biofuel and other commodities.

Each individual farm has its own specific characteristics, which arise from variations in resource endowments and family circumstances. The household, its resources, and the resource flows and interactions at this individual farm level are together referred to as a farm system. A farming system is defined as a population of individual farm systems that have broadly similar resource bases, enterprise patterns, household livelihoods and constraints, and for which similar development strategies and interventions would be appropriate.

\section{Marketing Eficiency}

Market efficiency refers to the degree to which stock prices and other securities prices reflect all available, relevant information. Market efficiency was developed in 1970 by economist Eugene Fama, whose theory of efficient market hypothesis (EMH) stated it is not possible for an investor to outperform the market because all available information is already built into all stock prices. Investors who agree with this statement tend to buy index funds that track overall market performance and are proponents of passive portfolio management.

\section{Method}

The location of this research was in Muna Regency in which its society had been long enough in cultivating green beans. The study lasted four months, from August to November 2015. Considering the extent of the research location and limited resources, the sampling technique used was three-stage cluster sampling, that was dividing the district by sub-districts which were green bean-producing sub-districts, then, three subdistricts were selected. Furthermore, they were subdivided by villages, and each sub-district was chosen 1 
village of green beans producerpurposively. Thus, the research location waslocated in three villages spread over three sub-districts of Muna regency. The respondents were 22 of green beans farmers which were selected purposivelyfrom each elected village, so the total number of respondents were 66 people. The method of collecting primary data was done through direct interviews to the respondents, while secondary data was collected through publication searches from related institutions such as Central Bureau of Statistics and Agricultural Office of Muna regency and Southeast Sulawesi Province as well as the results of previous researchs. Data analysis method was descriptive statistics and analysis of farming efficiency was R-C Ratio.

$\mathrm{a}=\mathrm{R} / \mathrm{C}$

$\mathrm{R}=\mathrm{Py} . \mathrm{Y}$

$\mathrm{C}=\mathrm{FC}+\mathrm{VC}$

$\mathrm{a}=\{(\mathrm{Py} . \mathrm{Y}) /(\mathrm{FC}+\mathrm{VC})\}$

Explanation:

$\mathrm{R}=$ Revenue

$\mathrm{C}=$ Cost

Py $=$ Output price

$\mathrm{Y}=$ Output

$\mathrm{FC}=$ Fixed Cost

$\mathrm{VC}=$ Non-fixed cost $($ Variabel cost $)$

If:

$a<1$ : then declaredinefficient

a $>1:$ then declared efficient

$\mathrm{a}=1:$ then declared impasse (Not profit or loss)

\section{Result and Discussion}

\section{Farming efficiency of green beans}

Cultivation green beans requires farming costs that could be grouped in variable costs. Fixed cost indicates the amount of funds used to purchase fixed assets such as hoes, shovels, ariit, machetes and Land and Building Tax (UN), while Variable costs are the amount of funds used by farmers to purchase production facilities such as seeds, fertilizers, pesticides, and labor. The average total cost of green beans cultivation per hectare was IDR 1,420,560, while the average revenue amount was IDR 3,680,105 per hectare.

The result of farming efficiency analysis of green beans in Muna regency can be seen in table 2 below:

Table 2. The result of farming efficiency analysis of green beans in Muna regency.

\begin{tabular}{|c|l|l|l|l|}
\hline Muna Regency & $\begin{array}{l}\text { Average revenue } \\
\text { total(IDR/Ha) }\end{array}$ & $\begin{array}{l}\text { Average output price } \\
\text { (IDR/Ha) }\end{array}$ & R/C Ratio & Profit (IDR/Ha) \\
\cline { 2 - 5 } & 3.680 .105 & 1.420 .500 & 2.59 & 2.259 .545 \\
\hline
\end{tabular}

Regarding the result of efficiency analysis presented in table 2 shows that the level of farming efficiency of green beans had a sufficient level of efficiency or profitable to be cultivated as shown by the value of RC Ratio greater than 1 that was equal to 2.59, which meant that any expenditure of IDR 1 would obtainprofit by IDR 2.59 .

The implication of this finding suggests that the green beans need to be developed intensively by the community because it is quite profitable financially, and therefore need to be supported and encouraged by the local and national government through various policies and programs of agricultural development of food crops sspecially green beans. Thus, It could strengthen the availability of food to self-sufficiency green beans both at regional and national levels.

\section{Marketing Efficiency}

Marketing aspects to be discussed in this research were marketing channel and marketing margin.

\section{a. Analysis of Marketing Channel}

A product produced by farmers aims to be marketed to consumers and it is done through a particular marketing channel. Marketing of green beans product in Muna district consisted of main channel and other channels. The marketing channels of green beans were not sold only within the district but also outside it such as Kendari and Bau-Bau City which was distributed through Raha port. It startedwhen theproducer farmers of green beans sold their products to three parties namely local consumers, village and sub-district collectors. 
Figure 1 Marketing channel of green beans in Muna Regency of Southeast Sulawesi Province

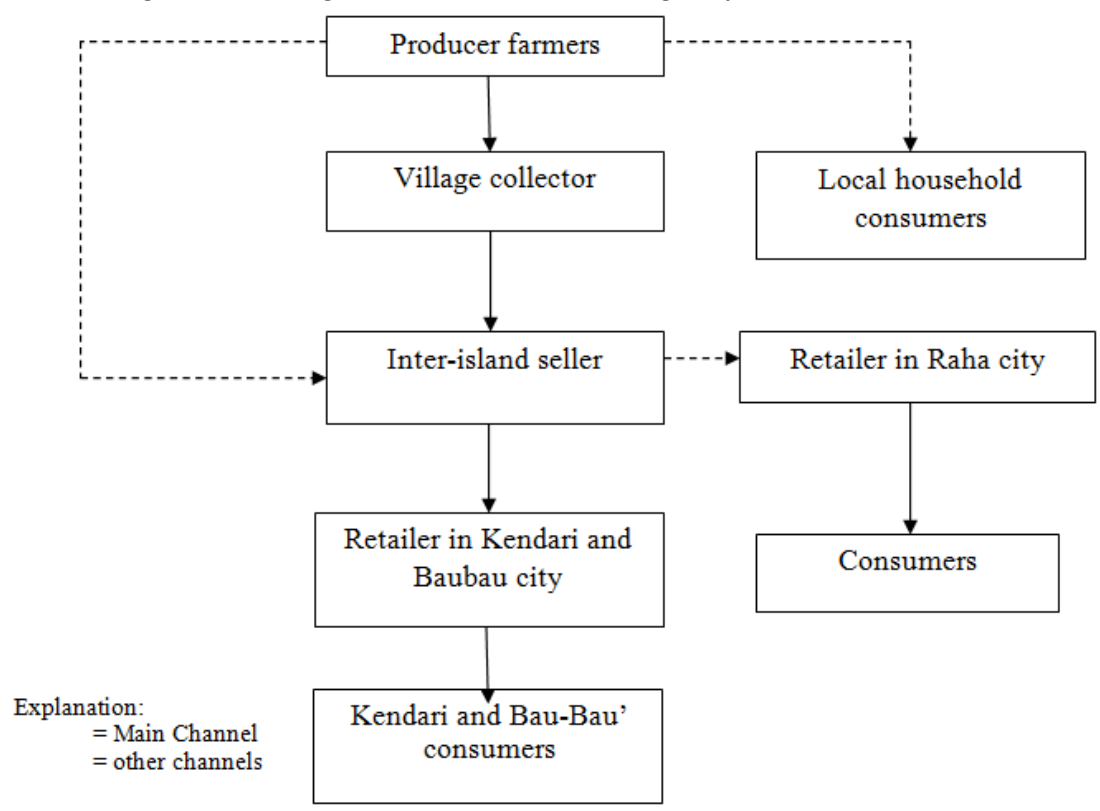

\section{b. Analysis of Marketing Margin}

Marketing margin is the deviation between the price paid by the end buyer and the price received by the farmers (producers). It is often used as an indicator of marketing efficiency. The amount of marketing margin on different marketing channels can be different, because it depends on the length of the marketing channel and, undertaken activities and the expected benefits of the marketing agencies involved in the marketing system. Table 3 shows the results of margin analysis, shared prices received by farmers and the ratio of profits and costs in marketing of green beans.

\section{Distribution of Marketing Margin}

Table 3 witnessesrelatively that the sub-district collector got the most benefits or advantages in the marketing system of green beans in Muna Regency which was about 15.60\%. It was due to higher sales volume, higher sales prices and higher capital expenditures, resulting in higher profits compared to other sellers (village collectors). Thus the longer the marketing channel,the greater its marketing margin was, hence the price at the end level of buyer will be more expensive because of its long marketing channel.

\section{Profit Ratio of Marketing Cost}

This analysis was shown to know the share prices received by farmers from the end buyer price presented as percentage. Most farmers sold green beans to marketing institutions (traders), while the rest of it was sold directly to consumers. The existence of several marketing channels usage caused margin rates, marketing costs and different benefits. Distribution of fair share among marketing actors is largely determined by marketing efficiency, while marketing efficiency is determined by marketing margins.

To find out the ratio of profit to marketing cost of the three marketing institutions used, the highest profit and the cost was at the level of sub-distict collector counted by 3.57 , followed by the retailer of $3.50 \%$ and the village collector 1, 09. The high profit-to-cost ratio of sub-district collectors was because of the greater ownership of capital investments.

Table 3. Structural distribution of marketing margin of green beans in Muna regency

\begin{tabular}{|c|c|c|c|}
\hline $\mathrm{Nu}$ & Descriptions & $\mathrm{RP} / \mathrm{Kg}$ & shares $(\%)$ \\
\hline 1 & Average cost received by farmers & 8.500 & 53,12 \\
\hline \multirow[t]{6}{*}{2} & Purchase price of village collector & 8.500 & 53,12 \\
\hline & a. $\quad$ Transport cost & 300 & 1,87 \\
\hline & b. $\quad$ Packing cost & 100 & 0,62 \\
\hline & c. $\quad$ Storage cost & 50 & 0,31 \\
\hline & d. Run-down cost & 100 & 0,62 \\
\hline & e. $\quad$ Profit margin & 600 & 3,75 \\
\hline \multirow[t]{5}{*}{3} & Purchase price of sub-district collector & 9.700 & 60,62 \\
\hline & a. $\quad$ Transport cost & 500 & 3,12 \\
\hline & b. $\quad$ Storage cost & 100 & 0,62 \\
\hline & c. $\quad$ Run-down cost & 100 & 0,62 \\
\hline & d. $\quad$ Profit margin & 2.500 & 15,6 \\
\hline
\end{tabular}


Analysis of Farming And Marketing Efficiency Of Green Beans In Muna Regency Of Southeast

\begin{tabular}{|l|l|l|l|}
\hline 4 & Purchase price of retailer & 12.900 & 80,62 \\
\hline & a. Transport cost & 400 & 1,87 \\
\hline & b. Storage cost & 100 & 0,06 \\
\hline & c. Run-down cost $\quad 100$ & 0,06 \\
\hline & d. Profit margin & 2.100 & 13,75 \\
\hline 5 & Purchase price of consumer & 16.000 & \\
\hline 6 & Profit ratio of marketing price: & & \\
\hline & a. Village collector & 1.09 & \\
\hline & b. Sub-district or inter-island collector & 3,57 & \\
\hline & c. Retailer & 3.50 & \\
\hline
\end{tabular}

Source: Processed Primer Data (2016)

Regarding the marketing cost structure in table 3 , it appears that transport cost represented the highest cost. This situation was caused by the poorinfrastucture and transportation facilities from the sub-district to the villages or inter-village.

The high marketing costs issued by either village or sub-disticts collectorsbecame less profitable for the producer farmers. In determining price, village-level collectors acted as price maker. This condition caused the village collectors trying to suppress the purchase price to maintain the desired profit. It might be interpreted that marketing costs tended to be charged to farmers. Therefore, some efforts to improve the efficiency of marketing costs were needed. The distribution of profit-to-cost ratio tended to be uneven that was the highest profit was obtained by inter-island traders and retailers counted by 3.57 and 3.50 respectively. The development of infrastructures in the villages was one of the ways to solve the problem of high costs marketing, and dissemination of information about marketing should be increased by the government.

\section{Conclusion}

1. Green bean farming in the Muna regency was relatively efficient and profitable, as indicated by the R/ C value greater than one with the $\mathrm{R} / \mathrm{C}$ value of 2.59 . This condition meant that every expenditure of IDR 1 in green bean farming activities will obtain a financial benefit of RP 2.59

2. The marketing of green beans in the region was channeled not only for local consumption but also sold out of the area such as Bau-Bau and Kendari. While from the efficiency aspect, it was relatively efficient as shown by share price received by farmer equal to 53.12 percent.

\section{Suggestion}

1. Regarding the analysis result of green bean farming efficiency in Muna regency, it is advisable to the government to socialize green beans cultivationincessantly and evenly on each district. This is important because it is a profitable business and can increase farmers' income.

2. Concerning the marketing analysis, to improve marketing efficiency and farmers' income, it is necessary to pay attention in reduce marketing costs through improvement in land transportation facilities and infrastructure within the villages and inter-village and the dissemination of market information. It is expected that this research result will be an information material for green beans farmer and local government as an effort to develop agribusiness or agroindustry of green beans.

\section{References}

[1] Badan Pusat Statistik Sulawesi Tenggara, 2012. Sulawesi Tenggara Dalam Angka. Kendari. BPS Sultra.

[2] Darmadjati, DS., Marwoto, DKS.,Swastika, DM.,Y. Hilman. 2005. Prosepek dan Arah Pengembangan Agribisnis Kedelai. Badan Litbang Jakarta

[3] Direktorat Jendral Bina Produksi Tanaman Pangan 2002 dalam Sudana Wayan. Perkembangan Jagung Pada Dekade Terakhir serta Peluang Pengembangannya Kedepan. Pusat Penelitian Sosial Ekonomi Pertanian Badan Litbang Pertanian, Departemen Pertanian Bogor diunduh dari internet pada tanggal 25 Februari Tahun 2015: http://ojs.unud.ac.id/index.php/soca/article/viewFile/4069/3058

[4] Geo, L. 2015. The Performance Of The Production And Marketing Of Non-Rice Food Commodity Strategies In Southeast Sulawesi. Proceeding ISBN 978-602-8161-81-7.

[5] Geo, L. 2015. Dinamika Produksi dan Pemasaran Jagung di Kabupaten Muna Provinsi Sulawesi Tenggara. Proceeding ISBN 978602-8161-75-6.

[6] Geo, L. 2015. Keragaman Produk Tanaman Pangan Antar Wilayah Di Provinsi Sulawesi Tenggara, Proceeding ISBN 978-6028161-76-3

[7] Geo, L. 2015. Pemetaan Produksi dan Kelayakan Finansial Usahatani Ubi Jalar Antar Wilayah Di Provinsi Sulawesi Tenggara, Makalah Seminar NasionalStrategi Akselerasi Pengembangan Industri Pertanian Mandiri dalam Pembangunan Poros Maritim.

[8] Geo, L. 2015. Dinamika Produktivitas Dan Kelayakan Finsial Usahatani Ubi Kayu Antar Wilayah Di Provinsi Sulawesi Tenggara. Majalah Ilmiah. ISSN:0854-0128.

[9] Geo, L. 2016. Produksi Dan Kelayakan Finansial Usahatani Jagung Di Wilayah Kabupaten Buton dan Konawe Selatan Provinsi Sulawesi Tenggara. Prosiding. ISBN:978-602-8161-86-2

[10] Geo, L. 2016. Analisis Efisiensi Usahatani dan Pemasaran Kacang Tanah di Wilayah Kabupaten Muna Provinsi Sulawesi Tenggara. Majalah Ilmuah. ISSN: 0852-0128.

[11] Geo, L. and Harafah, L.M., 2014. Kajian Ekonomi Tentang Produk Unggulan Non Beras Dalam PeR/Cepatan dan Perluasan Pembangunan Pertanian Tanaman Pangan di Sulawesi Tenggara. Hasil Penelitian MP3EI- Lembaga Penelitian UHO. 
[12] Geo, L dan Muthalib, A.A. 2015. Kajian Ekonomi Tentang Produk Unggulan Non Beras Dalam PeR/Cepatan dan Perluasan Pembangunan Pertanian Tanaman Pangan di Sulawesi Tenggara. Hasil Penelitian MP3EI- Lembaga Penelitian UHO.

[13] Gregor, Howard F. (July 1969). "Farm Structure in Regional Comparison: California and New Jersey Vegetable Farms". Economic Geography. Economic Geography, Vol. 45, No. 3. 45 (3): 209-225. doi:10.2307/143091. JSTOR 143091

[14] Harafah,L.M., Geo, L., and Muthalib, A.A. 2015. Economic Study of Non-Rice Consumption in Supporting Food Security (Study in Muna Regency of South East Sulawesi Indonesia). International Journal of Science and ReseaR/Ch ISSN (online) $2319-7064$.

[15] Harafah dkk, 2013. Kajian Ekonomi Konsumsi Non Beras Dalam Mendukung Ketahanan Pangan di Kabupaten Muna. Lemlit UHO.

[16] Mastur, 2011. Strategi Peningkatan Produktivitas dan Perluasan Areal Tanaman Jagung di Kalimantan Timur. Prosiding Seminar Nasional. Serealia. Balai Penelitian Tanaman Serealia. Maros .

[17] Padangaran, Ayub M. 2013. Analisis Kuantitatif Pembiayaan Perusahaan Pertanian. IPB Press. Bogor.

[18] Palimbong P. 2010. Pangan Non-Beras dalam Rangka Ketahanan Pangan. (http://kabarlandak.blogspot.com/2010/04/pangan-nonberas-dalam-rangka ketahanan.html.).

[19] Rachman, Handewi PS dan M. Ariani, 2008. Penganeka Ragaman Konsumsi Pangan di Indonesia : Permasalahan dan Implikasi Untuk Kebijakan dan Program. 